Vol. 6, No. 1, 2021

\title{
APPLICATION OF SALICYLIC ACID IN GROWING BETA VULGARIS L. PLANTS IN THE CONTEXT OF SUSTAINABLE AGRICULTURAL PRODUCTION
}

\author{
Olga Tsvilynyuk ${ }^{1}$, Liliia Telehii ${ }^{2}$ \\ ${ }^{1}$ Biological Faculty, \\ Ivan Franko National University of Lviv, \\ 4, M. Hrushevskoho Str., Lviv, 79005, Ukraine \\ ${ }^{2}$ Institute of Chemistry and Chemical Technologies, \\ Lviv Politechnic National University, \\ 12, S. Bandery Str., Lviv, 79013, Ukraine \\ tsvilya@gmail.com
}

https://doi.org/10.23939/ep2021.01.021

Received: 12.11 .2020

(C) Tsvilynyuk O., Telehii L., 2021

\begin{abstract}
The use of synthetic phytohormones is a promising technology for intensification and greening of agricultural production. Salicylic acid, among the others, is of particular interest. It causes anti-stress activity in plants in response to various adverse environmental factors in the laboratory. The analysis of the results of model field experiments showed that the use of salicylic acid for pre-sowing treatment of beet seeds varieties "Detroit" and "Egyptian flat" improves the habitus of mature plants, increases their water conservation capacity under adverse growth conditions (concentration $1 \cdot 10^{-4} \mathrm{M}$ ). In adverse climatic conditions (initially excess moisture, and during the period of active growth and accumulation of nutrients drought), the mass of the roots of both varieties of beets doubled under the influence of salicylic acid at a concentration of $1 \cdot 10^{-5} \mathrm{M}$ and increased 1.7 times at a concentration of $1 \cdot 10^{-4} \mathrm{M}$ (Detroit beets). This indicates a variety-specific reaction of beet plants to different concentrations of salicylic acid used for pre-sowing seed treatment. The use of salicylic acid in the cultivation of beets can become a priority in the transition of agriculture to the principles of sustainable development in a changing climate.
\end{abstract}

Key words: beets, salicylic acid (SA), drought, water holding capacity, root mass.

\section{Introduction}

Among the goals of sustainable development adapted for Ukraine (2015-2030), the goal of overcoming hunger and developing agriculture is the second most crucial objective after overcoming poverty. To achieve it, a number of tasks should be performed including the key one which is to ensure the creation of sustainable food production systems that contribute to the preservation of ecosystems and gradually improve the quality of land and soil, primarily through the use of innovative technologies (Sustainable Development Goals, 2017).

One of the promising technologies for intensification of agricultural production with its simultaneous greening is the use of synthetic plant growth regulators, which are the analogues of the natural regulators. The results of numerous laboratory studies and practical tests show that the use of plant growth regulators in agriculture is one of the most affordable and highly cost-effective measures to increase the productivity of major crops and improve their quality, especially in a changing climate (Kosakivska, 2003). However, their influence varies depending on the type of plants, treatment application method, its concentration, climatic and edaphic factors. That is, the large-scale application of growth regulators require preliminary model field research in the natural conditions.

Therefore, the aim of our work was to study the effect of pre-sowing treatment of beet plant seeds with artificially synthesized phytohormone salicylic acid (SA) in the model field studies. In the literature available to us we could not find any reports on the use of SA during the cultivation of beet plants in the open ground. The concentrations of working solutions for the research were

For citation: Tsvilynyuk O., Telehii L., 2020. Application of salicylic acid in growing beta vulgaris 1. plants in the context of sustainable agricultural production. Journal Environmental Problems. Vol. 6, No. 1. p. 21-27. DOI: https://doi.org/10.23939/ep2021.01.021 
measured based on the analysis of numerous results of laboratory researches where plants of different types under the influence of SA resisted adverse environmental factors (high temperature, lack of moisture, etc.) (Anosheh et all., 2012; Askari, Ehsanzadeh, 2015; Muhammad et all., 2007; Sibgha et all., 2009)

\section{Experimental part}

Model field studies of the effects of pre-sowing treatment with salicylic acid (SA) of beetroot seeds (Beta vulgaris L) of Detroit and Egyptian flat varieties were conducted on typical low-humus chernozem in Velykyi Hlybochok, Ternopil district, Ternopil region. Calibrated beet seeds were soaked for three hours in SA solutions of three concentrations $(1 \times ; 5 \times ; 1 \times)$ and sown in the wet state on March 21, 2019. Selection of plants for research was carried out on May 18, June 5, August 2.

The length of the third leaf of every beet seedlings was measured. The amount of dry matter in the roots was measured by thermostatic-weight method (drying in an oven at a temperature of $105 \mathrm{oC}$ ) in accordance with ДСТУ ISO 6496: 2005. Water holding capacity was measured using the method of withering according to Arland (Kaliničenko, 2003). The cut leaves of the test plants were weighed after 60, 120, 180 minutes and 24 hours. The amount of water left in the leaf characterizes the value of water holding capacity. The results were statistically processed using Microsoft Excel software package. The significance of the difference between the variants was assessed by Student's t-test using a $5 \%$ significance level (Kučerenko et all., 2001). The weather conditions during the study period deviated significantly from the norm. The average temperature in March was $4.6^{\circ} \mathrm{C}$ which is $4{ }^{\circ} \mathrm{Chigher}$ than normal. Also, this period was very dry $(8.1 \mathrm{~mm}$ of precipitation, the norm is $29 \mathrm{~mm}$ ). April and May, on the contrary, were accompanied by heavy rains and a strong excess of precipitation (79 and $105 \mathrm{~mm}$, the norm is 47 and $72 \mathrm{~mm}$, respectively). As a result, July and August were very dry (24 and $12 \mathrm{~mm}$, the norm is 93 and $66 \mathrm{~mm}$ ) (Climate-Data.org., 2019). It should be noted that the temperature of each month in the period when the study was conducted either exceeded (in March by $4{ }^{\circ} \mathrm{C}$, April $-1.5{ }^{\circ} \mathrm{C}$, June $-3{ }^{\circ} \mathrm{C}$, August $2.3^{\circ} \mathrm{C}$ ), or was equal to normal (in May and July).

\section{Results and Discussion}

\subsection{Beet leaf length under the influence of salicylic acid}

Laboratory studies have shown that salicylic acid is a phytohormone that affects the formation of phytoimmunity on the one hand, and on the other hand, regulates the growth and development of the plant organism under stress (Kolupaev, 2010). On the first time point of model field research (May 18, 2019) of the SA effect on the beet plants in the juvenile phase, no significant difference between the control and experimental variants in leaf length was found (Table 1, Figs. 1, 2). Plants were developing in a favorable temperature regime with optimal moisture supply.

The period preceding the second time point of the research (June 5, 2019) was marked by a slightly lower amount of precipitation relative to the norm (ClimateData.org., 2019). Metrics of the plants fluctuated. The longest beet leaves of Detroit variety were exposed to SA at a concentration of $1 \times 10^{-5} \mathrm{M}$, exceeding the control 1.25 times, and as for the beetroot of Egyptian flat variety, there was no significant difference from the control plants detected (Table 1). However, Detroit beet plants that grew under the influence of SA in the three studied concentrations have a high habitus compared to the control plants (Fig. 3). Beet plants of the Egyptian flat variety under the influence of SA at concentrations of $5 \times 10^{-5} \mathrm{M}$ and $1 \times 10^{-4} \mathrm{M}$ have a much better habitus than the control plants (Fig. 4) although the length of the leaf is not significantly different from the control plants (Table 1).

The length of the beetroot leaf in different periods of development ( $\mathrm{mm})$

\begin{tabular}{|c|c|c|c|c|}
\hline Research time & \multicolumn{4}{|c|}{ Detroit varieties } \\
\hline & Control & $1 \cdot 10^{-5} \mathrm{M}$ & $5 \cdot 10^{-5} \mathrm{M}$ & $1 \cdot 10^{-4} \mathrm{M}$ \\
\hline 18.05 .2019 & $84.8 \pm 7.71$ & $85.0 \pm 7.84$ & $87.7 \pm 6.83$ & $87.3 \pm 7.74$ \\
\hline 05.06 .2019 & $212.8 \pm 20.39$ & $263.3 \pm 11.43$ & $201.5 \pm 13.87$ & $228.6 \pm 22.7$ \\
\hline & \multicolumn{4}{|c|}{ Egyptian flat varieties } \\
\hline 18.05 .2019 & $57.8 \pm 5.04$ & $72.3 \pm 8.46$ & $75.8 \pm 3.10$ & $59.6 \pm 2.51$ \\
\hline 05.06 .2019 & $228.3 \pm 24.63$ & $233.8 \pm 11.82$ & $258.6 \pm 18.82$ & $248.3 \pm 20.36$ \\
\hline
\end{tabular}




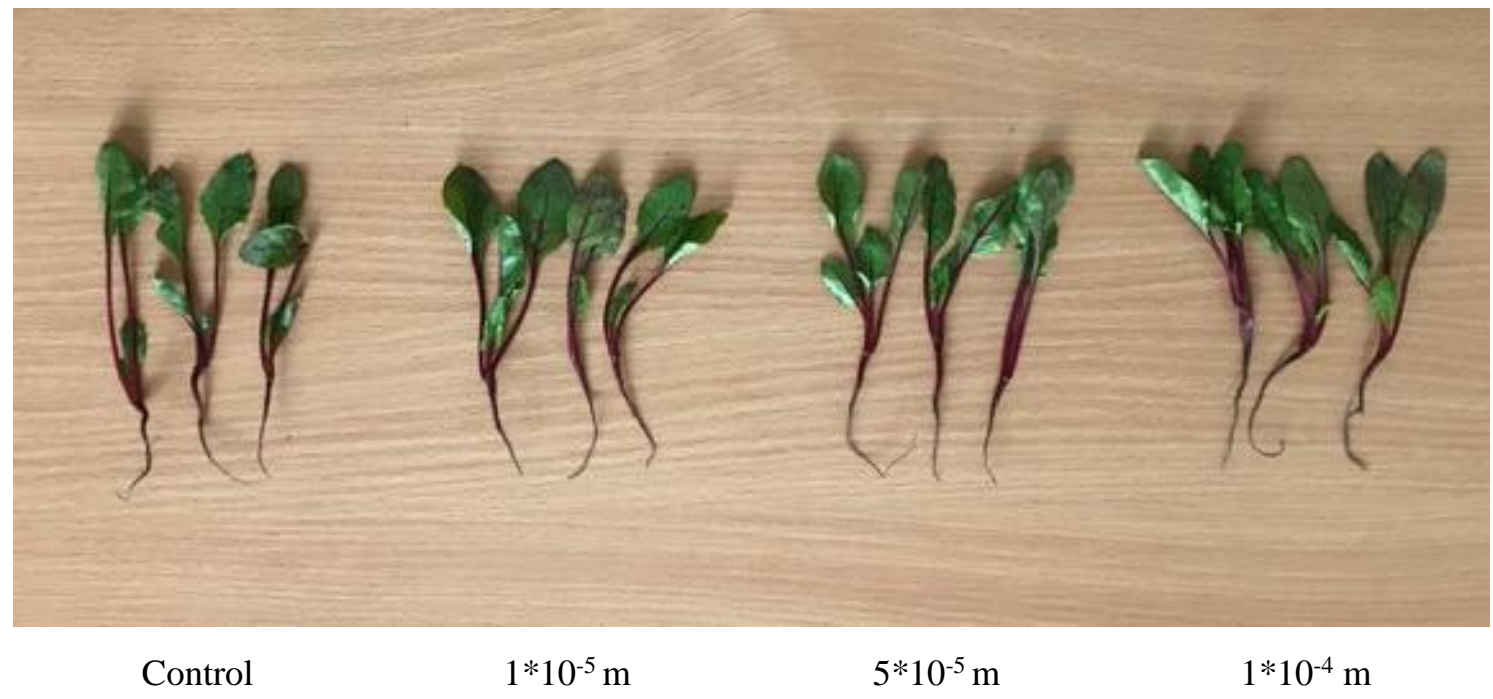

Fig. 1. Young plants of 'Detroit' beetroots under the influence of salicylic acid (18.05.2019)

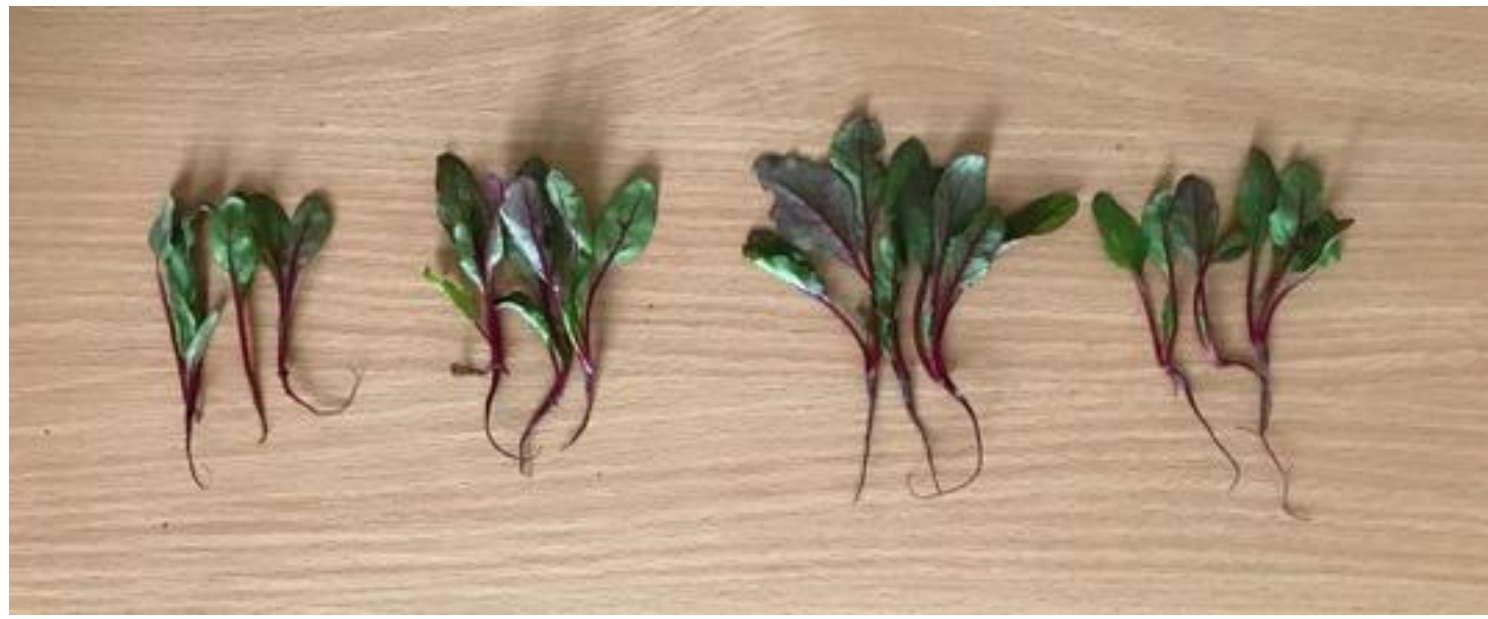

Control

$1 * 10^{-5} \mathrm{~m}$

$5 * 10^{-5} \mathrm{~m}$

$1 * 10^{-4} \mathrm{~m}$

Fig. 2. Young plants of 'Egyptian flat' beetroots under the influence of salicylic acid (18.05.2019)

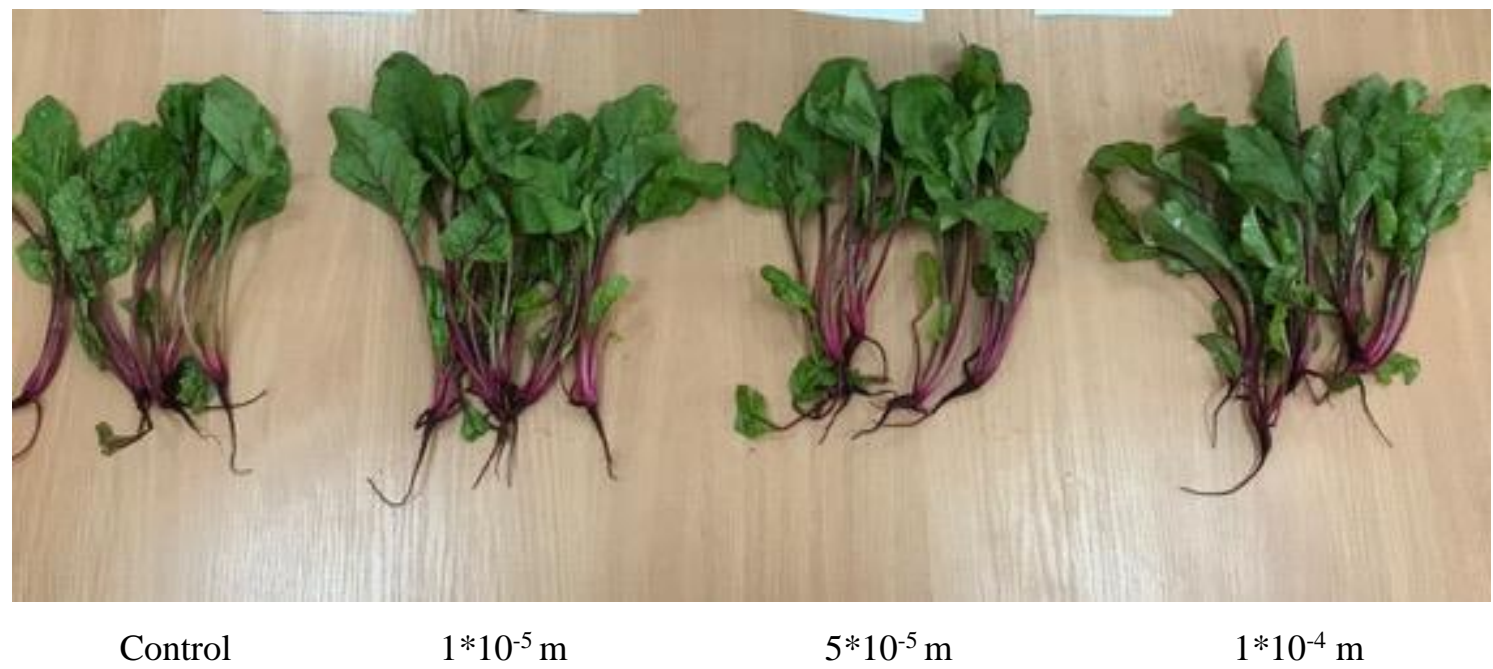

Fig. 3. Young plants of 'Detroit' beetroots under the influence of salicylic acid (05.06.2019) 


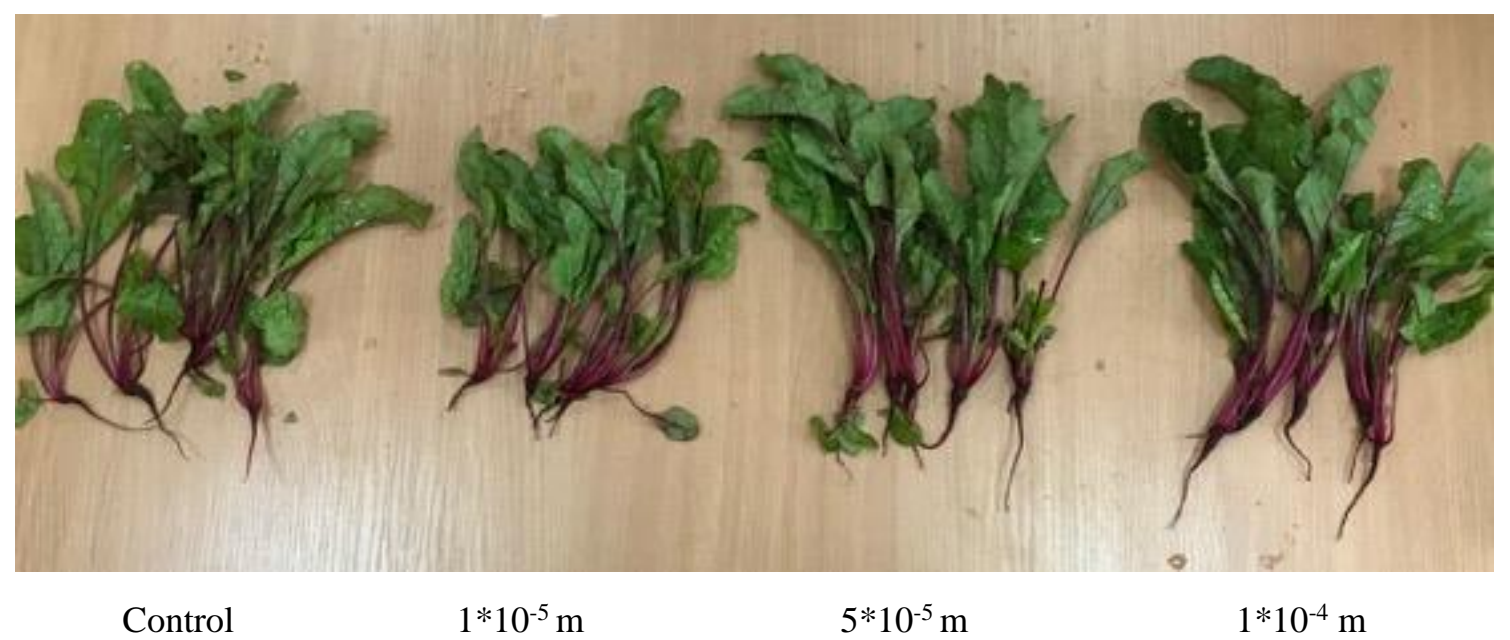

Fig. 4. Young plants of 'Egyptian flat' beetroots under the influence of salicylic acid (05.06.2019)

Plant metrics are an important indicator of plant development, but a healthy appearance, i.e. habitus, does not always correlate with high metrics.

\subsection{The effect of salicylic acid on the water content of beet leaves}

Water holding capacity of the plants, i.e. the ability of the organism (cells) to retain water in specific environmental conditions was also researched. This indicator is very important, it may indicate the degree of drought resistance of the plant (Bjeljajeva, 2014). It was evaluated by the amount of moisture lost from the leaf. The dynamics of water yield of beet leaves of both varieties under the influence of different concentrations of SC also did not differ from the control plants at this stage of plant development (Fig. 3, Fig. 4). Obviously, this is due to the fact that the plants were growing and developing in favorable climatic conditions (ClimateData.org., 2019).

In conditions of partial lack of moisture, the water holding capacity of the leaves has changed. The least moisture was lost by the leaves of beet plants of both varieties, the seeds of which were soaked in a $1 \times 10^{-4} \mathrm{M}$ solution of SA. Under the influence of other concentrations of salicylic acid, the water-holding capacity of beet leaves at this stage of research did not differ significantly from the control (Fig. 7, Fig. 8).

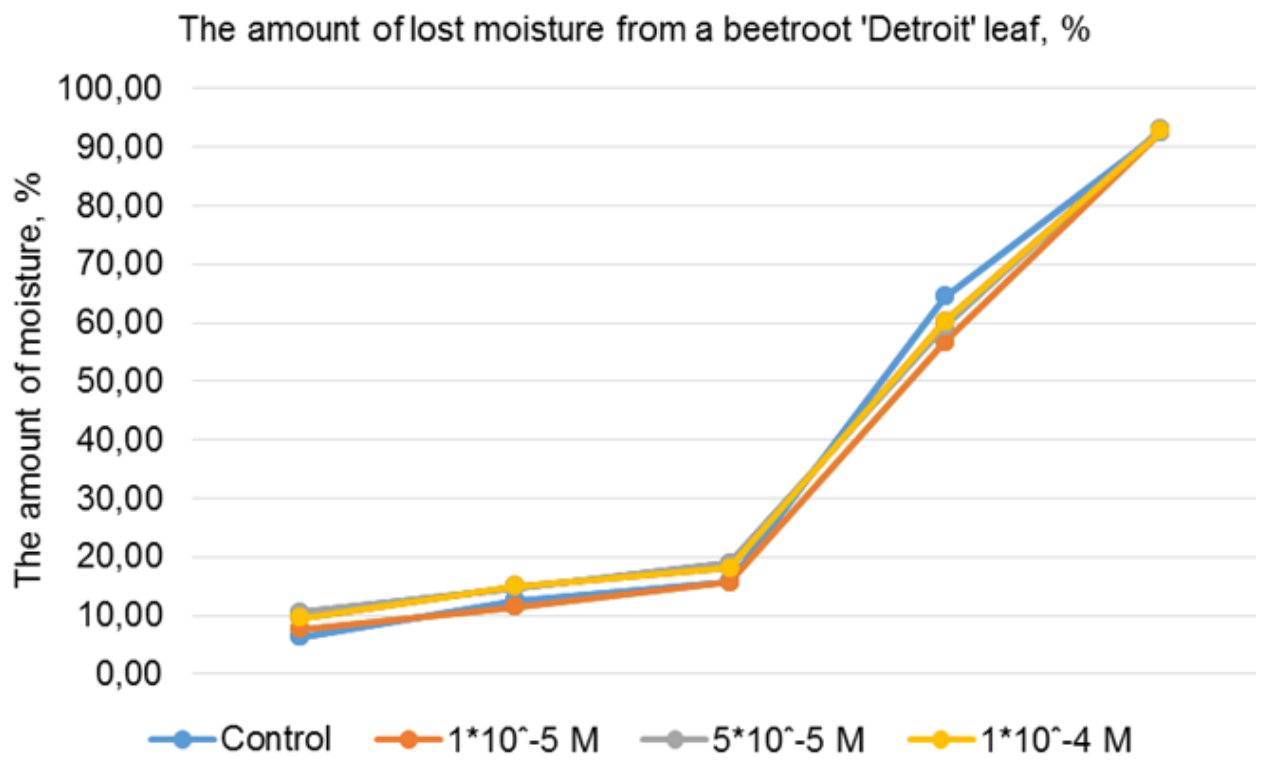

Fig. 5. Dynamics of water yield (in \%) by leaves of beetroot plants of the Detroit variety under the influence of salicylic acid (18.05.2019) 
The amount of lost moisture from a beetroot 'Egyptian flat ' leaf, \%

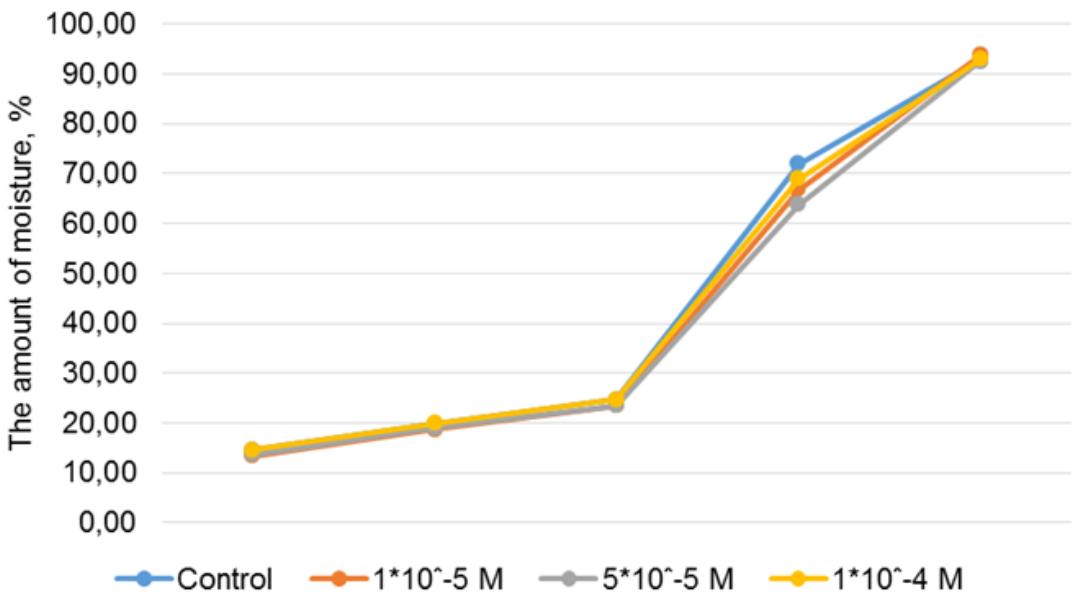

Fig. 6. Dynamics of water yield (in \%) by leaves of beetroot plants of the Egyptian flat variety under the influence of salicylic acid (18.05.2019)

\section{The amount of lost moisture from a beetroot 'Detroit' leaf, \%}

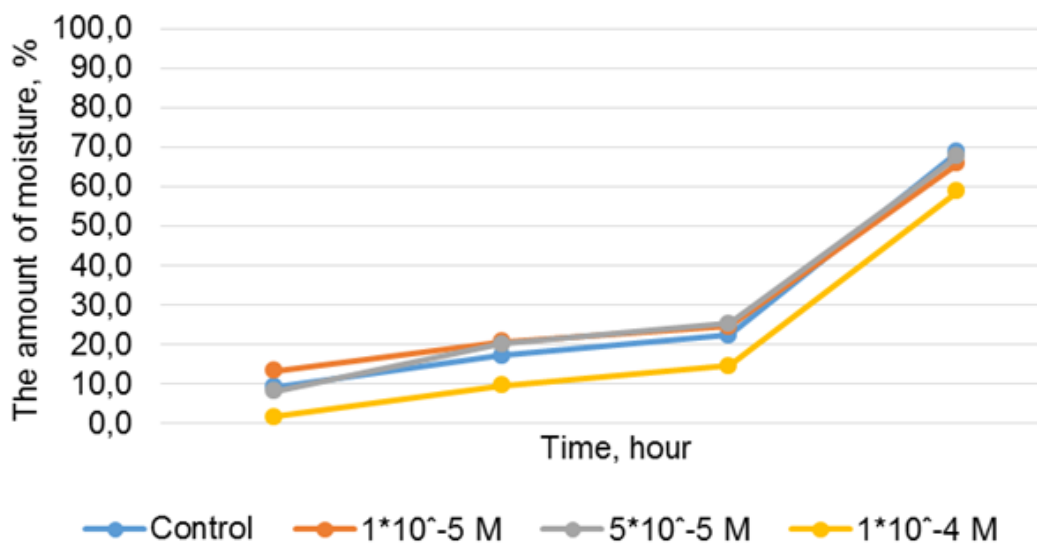

Fig. 7. Dynamics of water yield (in \%) by leaves of beetroot plants of the Detroit variety under the influence of salicylic acid (05.06.2019)

\section{The amount of lost moisture from a beetroot 'Detroit' leaf, \%}

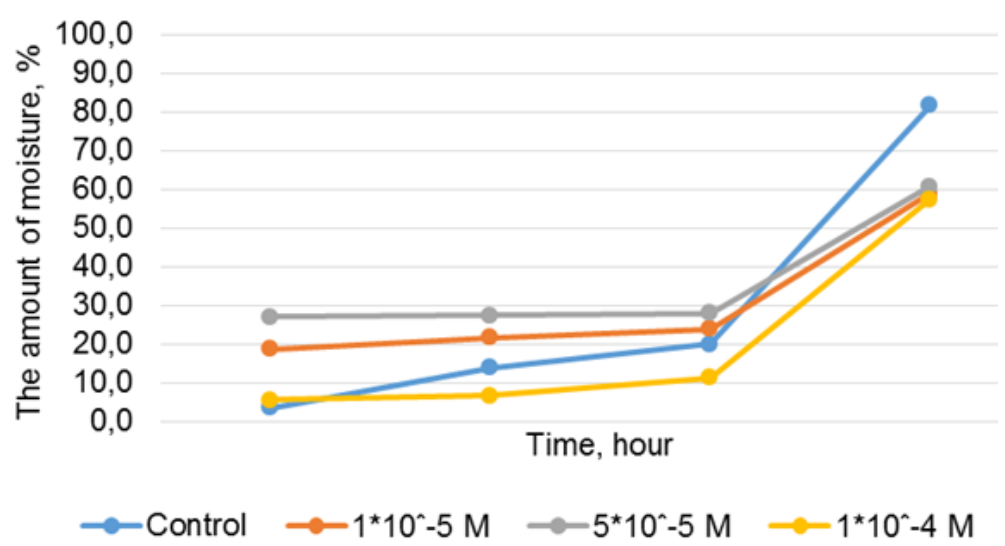

Fig. 8. Dynamics of water yield (in \%) by leaves of beetroot plants of the Egyptian flat variety under the influence of salicylic acid (05.06.2019) 
The water holding capacity of the plant directly affects its productivity.

\subsection{Mass of beet roots under the influence of salicylic acid}

Environmental factors that increase the rate of water yield of the plants (i.e. high temperature, lack of moisture) reduce their productivity. The period preceding the third time point of the research (August 2, 2019) was arid with only $23 \%$ of precipitation falling relative to the norm. However, the productivity of the studied plants under the influence of SC, which was assessed by the weight of the root crop, increased. Beetroot of the Detroit variety (Table 2, Fig. 9) and the Egyptian flat variety (Table 2, Fig. 10.) had the largest mass (2 times greater than in the control) of roots whose seeds were treated with SC in concentration $1 \cdot 10^{-5} \mathrm{M}$. Also, under the influence of $\mathrm{SA}$ at a concentration of $1 \cdot 10^{-4} \mathrm{M}$, the weight of Detroit beet roots increased 1.7 times relative to the control plants.

Weight of root beet $(\mathrm{g})$ under the influence of salicylic acid as of 02.08 .2019

Table 2

\begin{tabular}{|l|l|l|l|}
\hline Control & $1 \cdot 10^{-5} \mathrm{M}$ & $5 \cdot 10^{-5} \mathrm{M}$ & $1 \cdot 10^{-4} \mathrm{M}$ \\
\hline Detroit varieties & $176.7 \pm 42.5$ & $133.1 \pm 43.8$ & $149.6 \pm 19.6$ \\
\hline $86.7 \pm 19.7$ & $117.8 \pm 26.5$ & $110.7 \pm 39.2$ & $108.7 \pm 35.60$ \\
\hline Egyptian flat varieties
\end{tabular}

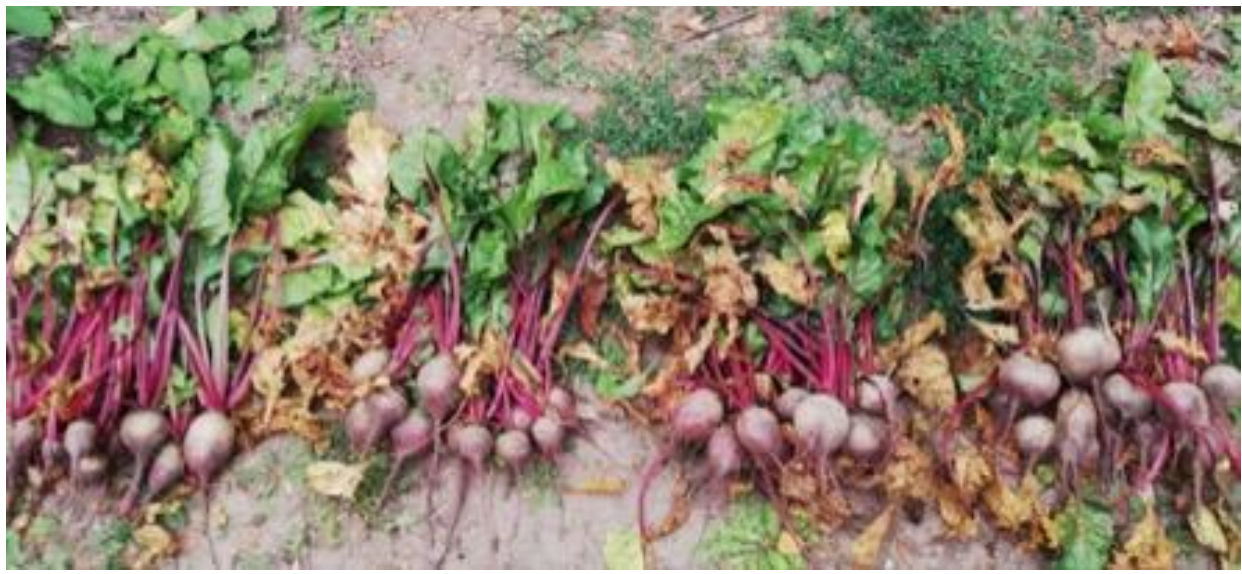
Control
$1 * 10^{-5} \mathrm{~m}$
$5 * 10^{-5} \mathrm{~m}$
$1 * 10^{-4} \mathrm{~m}$

Fig. 9. General view of 'Detroit' beetroots plants under the influence of salicylic acid (02.08.2019)

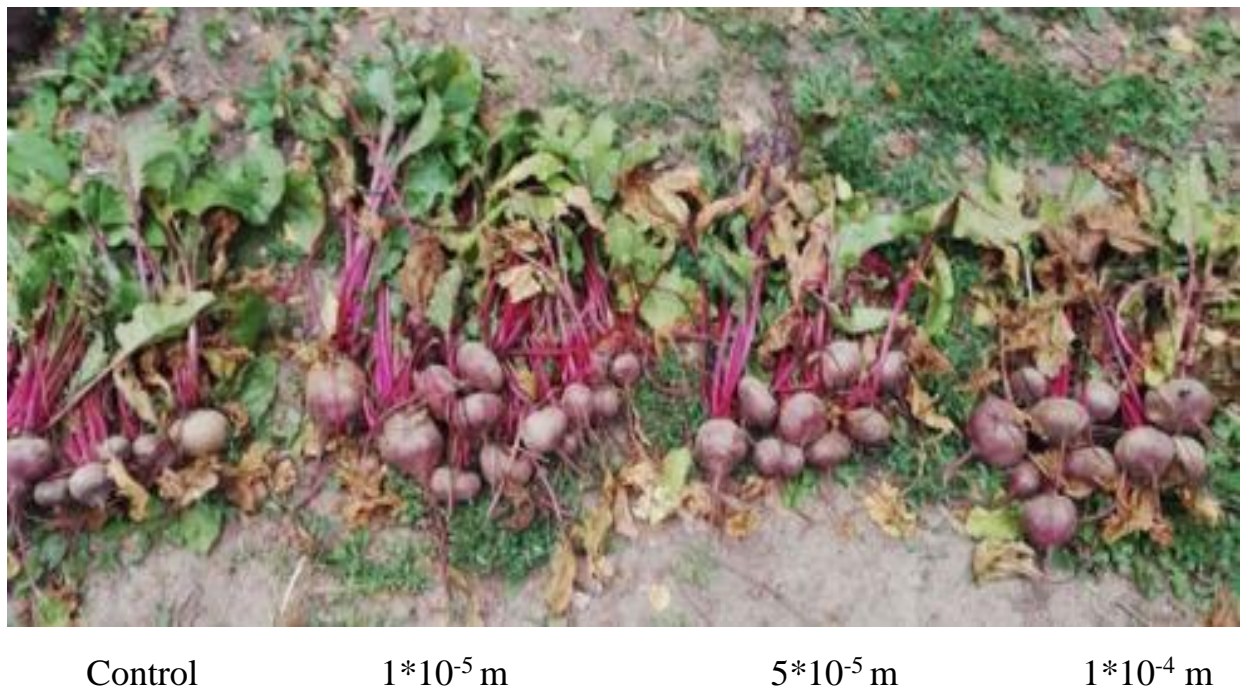

Fig. 10. General view of 'Egyptian flat' beetroots plants under the influence of salicylic acid (02.08.2019) 
Consumer quality of beetroots is determined not only by quantitative but also qualitative indicators. Among them, the amount of dry matter is very important. It is known that the treatment of plants with some exogenous phytohormones increases their productivity by stimulating tissue hydration. Simultaneously, the amount of dry matter is reduced (Rademacher, 2000).

According to the literature, the total amount of dry matter in the roots of beets should range from 13 to $20 \%$ (Puzik, Hordijenko, 2011). Under the influence of SA of the studied concentrations, the amount of dry matter in the roots of Detroit and Egyptian beets did not differ significantly from the amount in the control plants despite the higher weight (Table 3). This is the evidence of the high quality of the harvest.

Therefore, artificially synthesized phytohormone salicylic acid which is freely sold and is cheap has a long aftereffect in the plant body with exogenous single use (soaking the seeds). In small quantities it can increase the productivity of beetroots growing in conditions of water scarcity.

Dry matter content ( \%) in beet root under the action of salicylic acid as of 02.08.2019

\begin{tabular}{|c|c|c|c|}
\hline & $1 \cdot 10^{-5} \mathrm{M}$ & $5 \cdot 10^{-5} \mathrm{M}$ & $1 \cdot 10^{-4} \mathrm{M}$ \\
\hline \multicolumn{3}{|c|}{ Detroit varieties } \\
\hline $16.1 \pm 2.4$ & $18.4 \pm 3.1$ & $17.3 \pm 1.7$ & $15.8 \pm 1.9$ \\
\hline \multicolumn{4}{|c|}{ Egyptian flat varieties } \\
\hline $19.2 \pm 1.3$ & $19.6 \pm 2.5$ & $16.8 \pm 3.4$ & $17.7 \pm 3.0$ \\
\hline
\end{tabular}

\section{Conclusions}

1. The use of salicylic acid for pre-sowing treatment of beet seeds of Detroit and Egyptian Flat varieties improves the habitus of plants in the immature phase in all studied concentrations, increases their watersaving ability in unfavorable growth conditions at a concentration of $1 \cdot 10^{-4} \mathrm{M}$.

2. The mass of roots of both varieties of beets doubled under the influence of salicylic acid at a concentration of $1 \cdot 10^{-5} \mathrm{M}$, and increased 1.7 times under the influence of a concentration of $1 \cdot 10^{-4} \mathrm{M}$ (Detroit beets) in adverse climatic conditions: firstly excess moisture, and in the period of active growth and accumulation of nutrients - drought.

3. Plants of beet varieties respond differently to different concentrations of salicylic acid used for presowing seed treatment depending on the variety.

4. The use of salicylic acid in the cultivation of beets may become a priority in the transition of agriculture to the principles of sustainable development in the changing climate.

\section{References}

Anosheh, H. P., Emam, Y., Ashraf, M., \& Foolad, M. R. (2012). Exogenous application of salicylic acid and chlormequat chloride alleviates negative effects of drought stress in wheat. Advanced Studies in Biology, 4 (11), 501-520.

Askari, E., \& Ehsanzadeh, P. (2015). Drought stress mitigation by foliar application of salicylic acid and their interactive effects on physiological characteristics of fennel (Foeniculum vulgare Mill.) genotypes. Acta Physiologiae Plantarum, 37(4), 33-47.

Belyaeva, Yu. V. (2014). Rezultatyi issledovaniya vodouderzhivayuschey sposobnosti listovyih plastinok Betula pendula Roth. proiznastayuschey $\mathrm{v}$ usloviyah antropogennogo vozdeystviya. Izvestiya Samarskogo nauchnogo tsentra Rossiyskoy akademii nauk, 16 (5), 1654-1659. (in Russian). Retrieved from http://www.ssc.smr.ru/

Climate-Data.org. (2019). Bushfire resources: Ukraine climate: weather by month for Ukraine. Retrieved from https://en.climate-data.org/europe/ukraine-231/

Kaliničenko, O. (2003). Dekoratyvna dendrolohija. Navčal'nyj posibnyk. Kyiv: Vysoka škola. [in Ukrainian]

Kolupaev, J. (2010). Formyrovanye adaptyvnych reakcyj rastenyj na dejstvye abyotyčeskych stressov. Kyiv: Osnova. [in Russian]

Kosakivs'ka, I. (2003). Fizioloho-biochimični osnovy adaptaciï roslyn do stresiv. Kyiv: Stal'. [in Ukrainian]

Kučerenko, M., Babenjuk, J., \& Vojcic'kyj, V. (2001). Sučasni metody biochimičnych doslidžen'. Kyiv: Ukrsociocentr. [in Ukrainian]

Muhammad, A., Habib R., \& Muhammad, A. (2007). Does exogenous application of salicylic acid through the rooting medium modulate growth and photosynthetic capacity in two differently adapted spring wheat cultivars under salt stress?. Jornal of Plant Physiology, 164 (6), 685-694. doi: https://doi.org/ 10.1016/j.jplph.2006.05

Puzik, L., \& Hordijenko, L. (2011). Technolohija zberihannja plodiv, ovočiv ta vynohradu. Navč. posibnyk Chark. nac. ahrar. un-t im. V.V. Dokučajeva. Charkiv: KP "Mis'ka drukarnja". (in Ukrainian)

Rademacher, W. (2000). Growth Retardants: Effects on Gibberellin Biosynthesis and Other Metabolic Pathways. Annu. Rev. Plant Physiol. Plant Mol. Biol., 51, 501-531. Retrieved from https://europepmc.org/article/med/15012200

Sibgha N., Muhammad A., Mumtaz H., \& Amer, J. (2009). Exogenous application of salicylic acid enhances antioxidative capacity in salt-stressed sunflower (Helianthus annuus L.) plants. Pakistan Journal of Botany, 41 (1), 473-479. Retrieved from https://www.researchgate.net/

Sustainable Development Goals: Ukrain. (2017). Bushfire resources: National report. Retrieved from http://un.org.ua/ 